\title{
Effects of terracing on soil water and canopy transpiration of Chinese pine plantation in the Loess \\ Plateau, China
}

Handan Zhang ${ }^{1,2}$, Wei Wei ${ }^{1 *}$, Liding Chen ${ }^{1}$, Lixin Wang ${ }^{3}$

${ }^{1}$ State Key Laboratory of Urban and Regional Ecology, Research Center for

Eco-Environmental Sciences, Chinese Academy of Sciences, Beijing 100085, China.

${ }^{2}$ University of Chinese Academy of Sciences, Beijing 100049, China.

${ }^{3}$ Department of Earth Sciences, Indiana University-Purdue University Indianapolis

(IUPUI), Indianapolis 46202, United States

*Corresponding author: Wei Wei (weiwei@ rcees.ac.cn), Tel.: +86-10-6291-8673,

Fax: +86-10-6291-3840. 
Hydrol. Earth Syst. Sci. Discuss., doi:10.5194/hess-2016-223, 2016

Manuscript under review for journal Hydrol. Earth Syst. Sci.

Published: 18 May 2016

(c) Author(s) 2016. CC-BY 3.0 License.

\section{Abstract}

2 Terracing has long been considered one of the most effective measures for soil water

3 conservation and site improvement. However, the quantitative effects of terracing on soil water

4 dynamics and vegetation water use have not been reported. To fill these knowledge gaps, in this

5 study, soil water content and canopy transpiration were monitored in both terrace and slope

6 environments in the semiarid Loess Plateau of China in 2014 and 2015. Results showed that

7 terracing increased soil water content of different soil layers. Mean soil water content of the

8 terrace site was $25.4 \%$ and $13.7 \%$ higher than that in the slope site in 2014 and 2015, and canopy

9 transpiration at the terrace site increased by $9.1 \%$ and $4.8 \%$, respectively. Canopy conductance at

10 the terrace site was 3.9\% higher than that at the slope site and it decreased logarithmically with

11 vapor pressure deficit. This study highlighted the critical role of terracing in increasing the soil

12 water content and mitigating water stress in semiarid environments. Thus, terracing has the

13 potential to enhance sustainable vegetation restoration in water-limited regions.

14 Keywords: terracing; sap flux density; canopy conductance; water stress; Loess Plateau

\section{Introduction}

16 Terraces constitute a crucial engineering measure to control erosion, raise crop yields, and

17 maintain sustainable agroforestry. By leveling hillslopes, terraces seek to create better planting

18 surfaces for mitigating water loss and conserving soil (LaFevor, 2014; Zhang et al., 2014).

19 Terracing has been established as the main measure for soil and water conservation for fields

20 with gradients under 25 degrees (Li et al., 2011; Li et al., 2012b). It has been determined that

21 terracing in such locations can reduce both flood runoff and the sediment transport modulus (Bai

22 et al., 2015; Li et al., 2014a), and that the soil water conditions can be improved noticeably

23 (Courtwright and Findlay, 2011; Huo and Zhu, 2013). 
Hydrol. Earth Syst. Sci. Discuss., doi:10.5194/hess-2016-223, 2016

Manuscript under review for journal Hydrol. Earth Syst. Sci.

Published: 18 May 2016

(c) Author(s) 2016. CC-BY 3.0 License.

24 Transpiration as an important role part of the soil-plant-atmosphere continuum (Newman et al.,

25 2010) has considerable implications regarding forest management and water yields (Bosch et al.,

26 2014; Brito et al., 2015; Chang et al., 2014b), especially in regions where transpiration is a

27 fundamental datum for understanding the ecophysiology of planted forests (Wang et al., 2012a).

28 It is also central to the construction of an ecosystem-level water balance (Yang et al., 2009). Sap

29 flow measurement can provide insights on environmental limitations and it yields results

30 comparable with the estimates of water use for entire forest ecosystems (Chen et al., 2014b;

31 Chirino et al., 2011; Du et al., 2011; Kim et al., 2014). Previous studies have shown that sap flow

32 characteristics vary with species and growth status, as well as with meteorological,

33 environmental, and edaphic features (Brito et al., 2015; Du et al., 2011). In areas with

34 insufficient water, soil water conditions can restrict many physiological processes (Li et al.,

35 2014b). Plants in these areas tend to deepen and extend their root systems to exploit substantial

36 quantities of soil water for transpiration (Chen et al., 2014c; Limousin et al., 2009). Stomatal

37 closure as an important physiological process was employed by plants to regulate water use and

38 to prevent their hydraulic system from irreversible damage (Chirino et al., 2011). Sap flow

39 reduction caused by stomatal closure is considered to be the preliminary response of canopy

40 transpiration to water stress. Under water-sufficient conditions, differences in vapor pressure

41 deficit (VPD) determine the transpiration amount (Chen et al., 2014b). However, transpiration is

42 restricted by the plant's hydraulic conductance capacity and cannot exceed the amount of water

43 that can be obtained from the soil. Soil water influences stand transpiration through the water

44 fluxes within the root zone and the percolation of soil profile caused by different rainfall regimes

45 (Chen et al., 2014c). Based on pot experiments, Cui (2012) concluded that sap flow rates

46 dropped $84.7 \%$ under severe water stress (5.33\%) compared with that under non-stress (19.78\%) 
Hydrol. Earth Syst. Sci. Discuss., doi:10.5194/hess-2016-223, 2016

Manuscript under review for journal Hydrol. Earth Syst. Sci.

Published: 18 May 2016

(c) Author(s) 2016. CC-BY 3.0 License. conditions. Under saturated conditions, sap flow rates were found to reach 10 times of those in the dry season (Nie et al., 2005). The semiarid Loess Plateau region of China has experienced long-term serious soil erosion, vegetation degradation, and water loss (Zhang et al., 2008). Intense soil erosion has resulted in the decline of land productivity (under traditional agriculture) and environmental degradation (Wang et al., 2010). Because of the depletion of soil moisture and water shortages, there are many "dwarf and aged" trees in this region (Li et al., 2013). Hence, with the objectives of controlling erosion and conserving water resources, many investigations have been conducted into a wide range of soil management practices, including structural, agronomic, and biological measures (Jin et al., 2014; Yuan et al., 2016). Among these, terraces are a well-developed structural practice. Unlike native plants, many introduced species of vegetation usually have higher water demands (Chen et al., 2008; Yang et al., 2009). Thus, local soils have become extremely dry in both deep and shallow layers, diminishing the expected positive effects of afforestation in controlling soil erosion and improving the regional environment (Wang et al., 2012b; Yang et al., 2012). By analyzing four introduced plant species (Pinus tabulaeformis, Robinia pseudoacacia, Caragana korshinskill and Hippophae rhamnoides), Jian et al. (2015) drew the conclusion that in semiarid loess hilly areas, precipitation cannot meet the water loss caused by evapotranspiration in slope-scale. However, few studies have considered the effects of terracing on plant growth, nor its implications for regional ecological restoration.

This paired-site study focused on a small catchment in the western Loess Plateau of China to examine the effects of terracing on the soil water content and canopy transpiration. Similarly aged specimens of Chinese pine (P. tabulaeformis), being one of the main artificial plants in the area, were planted in both terrace and slope plots. The specific aims of this study were to (1) 
Hydrol. Earth Syst. Sci. Discuss., doi:10.5194/hess-2016-223, 2016

Manuscript under review for journal Hydrol. Earth Syst. Sci.

Published: 18 May 2016

(c) Author(s) 2016. CC-BY 3.0 License.

70 examine the effects of terracing on soil moisture dynamics; (2) identify the effect of terracing on

71 canopy transpiration.

$72 \quad 2$ Materials and methods

$73 \quad 2.1$ Site description

74 The study area was located in Anjiapo catchment in Dingxi County of Gansu Province, in the

75 western part of the Loess Plateau in China $\left(35^{\circ} 33^{\prime}-35^{\circ} 35^{\prime} \mathrm{N}, 104^{\circ} 38^{\prime}-104^{\circ} 41^{\prime} \mathrm{E}\right)$. This region has

76 a continental arid temperate climate with mean annual temperature and mean annual rainfall of

$776.3{ }^{\circ} \mathrm{C}$ and $421 \mathrm{~mm}$, respectively (1956-2010 period). Most of the rain falls during the summer

78 months in the form of thunderstorms. The mean annual pan evaporation reaches $1515 \mathrm{~mm}$. The

79 soil type belongs to calcic Cambisol (FAO, 1990), developed from loess material, with the

80 average soil depth varying from 40 to $60 \mathrm{~m}$. In this area, deep percolation can be neglected and

81 groundwater is unavailable for vegetation growth and restoration. Therefore, rainfall is the only

82 water source available for plants. The predominant vegetation types in the study area are native

83 grasses and introduced plants. In this study, two adjacent stands were chosen for the experiment:

84 one with natural sloping topography and the other that has been terraced for over 30 years (Fig.

85 1). Both sites were planted with specimens of $P$. tabulaeformis, a planted tree species typical of

86 the region (Chen et al., 2010; Wei et al., 2015).

87

88 Micrometeorological data such as air temperature $\left(T,{ }^{\circ} \mathrm{C}\right)$, solar radiation $\left(R_{a}, \mathrm{~W} \cdot \mathrm{m}^{-2}\right)$, relative

89 humidity $(R H, \%)$, and precipitation $(P, \mathrm{~mm})$ were obtained using a Vantage Pro2 automatic

90 weather station (Davis Company, USA) located in an open space about $500 \mathrm{~m}$ from the site.

91 Vapor pressure deficit (VPD, $\mathrm{kPa}$ ) was calculated based on the air temperature and relative

92 humidity as: 
Hydrol. Earth Syst. Sci. Discuss., doi:10.5194/hess-2016-223, 2016

Manuscript under review for journal Hydrol. Earth Syst. Sci.

Published: 18 May 2016

(C) Author(s) 2016. CC-BY 3.0 License.

(c) (i)
Hydrology and

Earth System

Sciences

Discussions
93

$$
V P D=0.611 \times \exp \left(\frac{17.27 T}{237.3+T}\right)(1-\mathrm{RH})
$$

94 Soil water content was monitored continuously using a HOBO U30 (Onset Computer

95 Corporation, Bourne, USA) from 2014 to 2015 within the upper $100 \mathrm{~cm}$ of the soil profile. There

96 were five probes in each instrument set to depths of $10,30,50,70$, and $90 \mathrm{~cm}$, respectively.

97 Relative extractable water (REW) was calculated as:

98

$$
R E W=\left(\theta-\theta_{\min }\right) /\left(\theta_{\max }-\theta_{\min }\right)
$$

99 where $\theta_{\max }$ and $\theta_{\min }$ are the maximum and minimum soil water content, respectively. The

100 value of REW varies between 0 and 1. Following Bréda et al. (2006), soil water conditions were

101 classified into severely stressed $(\operatorname{REW}=[0,0.1])$, moderately stressed $(\operatorname{REW}=[0.1,0.4])$, and

102 non-stressed $(\mathrm{REW}=[0.4,1])$.

$103 \quad 2.3$ Sap flux and transpiration measurements

104 Sap flux was monitored continuously from June 5, 2014 to October 10, 2015. At each studied

105 site, six individuals of $P$. tabulaeformis with different diameters at breast height $(\mathrm{DBH}, \mathrm{cm})$ were

106 selected, which represent the size classes within the site (Table 1). Sap flow was measured with

107 the improved Granier's thermal dissipation probe technique (Granier, 1985). The detailed

108 procedure for measuring sap flow was described in Zhang et al. (2015).

109 Sap flux density $\left(S F_{d}\right)$ was calculated by an empirical calibration equation:

$$
S F_{d}=0.714 \times\left(\frac{\Delta T_{\max }-\Delta T-\left(\Delta T_{R 1}+\Delta T_{R 2}\right) / 2}{\Delta T-\left(\Delta T_{R 1}+\Delta T_{R 2}\right) / 2}\right)^{1.231}
$$

111 where $S F_{d}$ is sap flux density $\left(\mathrm{mL} \cdot \mathrm{cm}^{-2} \cdot \mathrm{min}^{-1}\right) ; \Delta T, \Delta T_{R 1}$, and $\Delta T_{R 2}$ each represent the

112 temperature difference between probes (Zhang et al., 2015); and $\Delta T_{\max }$ is the maximum value 
Hydrol. Earth Syst. Sci. Discuss., doi:10.5194/hess-2016-223, 2016

Manuscript under review for journal Hydrol. Earth Syst. Sci.

Published: 18 May 2016

(c) Author(s) 2016. CC-BY 3.0 License.

113 of $\Delta T$ in cases when the tree was saturated, i.e., no radial tree-trunk increment, air humidity of

$114100 \%$, and transpiration near zero.

115 Sap flux $\left(S F, \mathrm{~kg} \cdot \mathrm{day}^{-1}\right)$ was obtained by the multiplication of sap flux density and sapwood area

$116\left(A_{s}, \mathrm{~cm}^{2}\right)$, neglecting the differences in radial profile (Chang et al., 2014a). It was calculated as:

$$
S F=1.44 S F_{\mathrm{d}} A_{s}
$$

118 Canopy transpiration $\left(E_{c}, \mathrm{~mm} \cdot \mathrm{day}^{-1}\right)$ was obtained from the $S F$ and crown projected area $\left(A_{\mathrm{c}}, \mathrm{m}^{2}\right)$

119 (Chang et al., 2014a) as:

$$
E_{\mathrm{c}}=S F / A_{c}
$$

121 Mean daily canopy conductance $\left(\mathrm{g}_{\mathrm{c}}, \mathrm{mm} \cdot \mathrm{s}^{-1}\right)$ was estimated from canopy transpiration $\left(E_{c}\right.$,

$122 \mathrm{~mm} \cdot \mathrm{h}^{-1}$ ) by using a simplified inverted Penman-Monteith equation (Luis et al., 2005):

$$
\mathrm{g}_{c}=\gamma \lambda E_{\mathrm{c}} / \rho c_{p} V P D
$$

124 where $\gamma$ is the psychometric constant $\left(\mathrm{kPa} \cdot{ }^{\circ} \mathrm{C}^{-1}\right), \lambda$ is the latent heat for vaporizing $\left(\mathrm{MJ} \cdot \mathrm{kg}^{-1}\right)$,

$125 \rho$ is the air density $\left(\mathrm{kg} \cdot \mathrm{m}^{-3}\right), c_{p}$ is the specific heat capacity of air $\left(\mathrm{MJ} \cdot \mathrm{kg}^{-1} \cdot{ }^{\circ} \mathrm{C}^{-1}\right)$, and the

$126 \operatorname{VPD}(\mathrm{kPa})$ is calculated from the air temperature and relative humidity. The value of $\mathrm{g}_{\mathrm{c}}$ was

127 assumed as approximate average stomatal conductance and considered to reflect the

128 physiological control of tree transpiration.

1292.4 Statistical analysis

130 DBH, sapwood area, and crown projected area were compared using the student $t$ test. For the

131 comparison of soil water content and canopy transpiration dynamics, non-parametric tests of

132 significance were used because of the autocorrelations in the time series data. The Wilcoxon

133 rank sum test, also known as the Mann-Whitney $U$ test, was used to test the differences in soil

134 water content and canopy transpiration between the terrace and slope sites. Curve fitting was 
Hydrol. Earth Syst. Sci. Discuss., doi:10.5194/hess-2016-223, 2016

Manuscript under review for journal Hydrol. Earth Syst. Sci.

Published: 18 May 2016

(C) Author(s) 2016. CC-BY 3.0 License.
Hydrology and

Earth System

Sciences

Discussions

135 performed using the OriginPro Version 8.0 software (OriginLab Corporation, USA) to establish

136 the relationship between canopy transpiration and soil water content, and between canopy

137 conductance and VPD. Statistical analyses were run using the SPSS version 17.0 software (SPSS

138 Inc., Chicago, IL, USA), for which, the significance level was set at 0.05.

\section{Results}

$140 \quad 3.1$ Soil water content

141 Under the same climatic conditions, soil water content showed differences between the natural

142 slope and terraces (Fig. 2). Data from the shallow layer $(0-20 \mathrm{~cm})$ were not analyzed because of

143 anthropogenic disturbance. In both years, statistically significant $(p<0.05)$ higher soil water

144 content was observed at the terrace site than that at the slope site (Fig. 2 a and b).

145 Depth-averaged soil water content of the terrace site was approximately $25.4 \%$ and $13.7 \%$ higher

146 than that at the slope site in 2014 and 2015, respectively. Moreover, the mean soil water contents

147 at both sites were higher in 2015 than that in 2014. Temporal variations of REW between 20-

$148100 \mathrm{~cm}$ (Fig. $2 \mathrm{c}$ and d) indicated that soil water conditions were stressed (REW < 0.4$)$ in both

149 sites during the two consecutive growing seasons. However, REW was $113.1 \%$ more at the

150 terrace site compared with that at the slope site during the two years. It was noted that soil water

151 was severely stressed $(\mathrm{REW}<0.1)$ in the slope site, whereas terracing improved the conditions

152 significantly.

$153 \quad 3.2$ Canopy transpiration

154 The diurnal variations of sap flux density $\left(S F_{d}\right)$ are shown in Fig. 3. In the growing season, $P$.

155 tabulaeformis had similar trends of variation at both sites, i.e., high flux density in the daytime

156 and low flux density at night. It varied between 0.02 and $0.23 \mathrm{~mL} \cdot \mathrm{cm}^{-2} \cdot \mathrm{min}^{-1}$ at the terrace site

157 and between 0.02 and $0.18 \mathrm{~mL} \cdot \mathrm{cm}^{-2} \cdot \mathrm{min}^{-1}$ at the slope site. $P$. tabulaeformis had $20.2 \%$ higher 
Hydrol. Earth Syst. Sci. Discuss., doi:10.5194/hess-2016-223, 2016

Manuscript under review for journal Hydrol. Earth Syst. Sci.

Published: 18 May 2016

(c) Author(s) 2016. CC-BY 3.0 License.

158 maximum sap flux density at the terrace site compared with that at the slope site. Canopy

159 transpiration was found to be $9.1 \%$ and $4.8 \%$ higher $(p<0.05)$ at the terrace site than that at the

160 slope site in 2014 and 2015, respectively. Annual variation analysis showed that the cumulative

161 canopy transpiration at both sites was higher in 2014 than that in 2015 (Fig. 4). In the naturally

162 sloping site, the cumulative canopy transpiration was $138.6 \mathrm{~mm}$ (32.9\% of potential

163 evapotranspiration (PET)) in 2014 and $107.6 \mathrm{~mm}$ (24.9\% of PET) in 2015. The corresponding

164 proportions at the terrace site were $35.7 \%$ and $26.0 \%$ in 2014 and 2015, respectively. Variation

165 in canopy transpiration between the slope and terrace sites increased with soil water content

166 variation $\left(p<0.0001, \mathrm{R}^{2}=0.20\right.$; Fig. 5).

$167 \quad 3.3$ Canopy conductance

168 We classified canopy conductance into two levels based on soil water conditions: REW > 0.1

169 (Fig. 6 a and b) and REW $<0.1$ (Fig. $6 \mathrm{c}$ and d). The relationships between canopy conductance

170 and solar radiation, between canopy conductance and VPD under corresponding soil water

171 conditions are shown in Figure 6. It exhibits that canopy conductance declined logarithmically

172 with VPD (Fig. $6 \mathrm{~b}$ and d), and there is no significant relationship between canopy conductance

173 and solar radiation (Fig. 6 a and c). When soil water conditions changed from wet (REW > 0.1)

174 to dry $($ REW < 0.1$)$, canopy conductance reduced by $12.3 \%$ and $24.7 \%$ at the slope and terrace

175 sites, respectively. Meanwhile, canopy conductance of P. tabulaeformis at the terrace site was up

176 to $3.9 \%$ higher than that at the slope site. The frequency of the $\mathrm{SF}_{\mathrm{d}}$ peak time suggested that $P$.

177 tabulaeformis suppressed $\mathrm{SF}_{\mathrm{d}}$ under high VPD conditions at both slope and terrace sites (Fig. 7).

178 The maximum $\mathrm{SF}_{\mathrm{d}}\left(\mathrm{SF}_{\mathrm{d}, \max }\right)$ was relatively similarly distributed before 14:00 local time (LT), i.e.,

$17961.1 \%$ at the slope site and 59.2\% at the terrace site. However, around 16:00 LT, closer to the

180 most frequent peak time of VPD, the proportion of $\mathrm{SF}_{\mathrm{d} \text {, max }}$ at the slope site was $33.3 \%$ less than 
Hydrol. Earth Syst. Sci. Discuss., doi:10.5194/hess-2016-223, 2016

Manuscript under review for journal Hydrol. Earth Syst. Sci.

Published: 18 May 2016

(c) Author(s) 2016. CC-BY 3.0 License.

181 that at the terrace site. Therefore, under the same conditions, terracing was found to alleviate the

182 sensitivity of stomatal response to ambient air humidity.

1834 Discussion

$184 \quad 4.1$ Effects of terracing on soil water recharge

185 A statistically significant $(p<0.05)$ higher soil water content was found at the terrace site

186 compared with that at the slope site (Fig. 2). Terraces, which interrupt natural slopes with a

187 series of gentle benches, can decrease the connectivity and integrity of overland flow, prolong

188 the residence time of water, and increase the infiltration (Molina et al., 2014). According to

189 Zhang et al. (2005), the soil profile in a terrace can be divided into three layers: the fast changing

190 layer, activity layer, and relatively stable layer. Water storage in the fast changing layer of a

191 terrace can be $7.2 \%$ higher than that in sloping land (Huo and Zhu, 2013). Similar to Wang et al.

192 (2014a), soil water content of the terrace site in this study was significantly higher $(p<0.05)$

193 than that at the slope site within $100 \mathrm{~cm}$ in each layer. The depth-averaged soil water content in

194 the terrace site was up to $25.4 \%$ higher than that at the slope site (Fig. 2). Similar results have

195 been obtained in studies that compared the effects of contour bench terrace systems in the

196 semiarid Negev in Israel (Stavi et al., 2015), examined terrace characteristics (Engdawork and

197 Bork, 2014), and detected the impact of restoring degraded terraces (LaFevor, 2014). Previous

198 works have reported that approximately $20 \%$ (to a potential 200\%) of total surface rainwater

199 could infiltrate into underground soil layers after terracing (Courtwright and Findlay, 2011), and

200 that 1.13 times more rainfall can be stored in a terraced system than that in sloping land (Li et al.,

201 2012a). The low REW indicated that the study area is under severe water stress, whereas the

202 large difference between the two sites (113.1\% more REW in the terrace site) suggested that the

203 construction of terraces could help increase soil water content. 
Hydrol. Earth Syst. Sci. Discuss., doi:10.5194/hess-2016-223, 2016

205 According to the results, the maximum sap flux density of $P$. tabulaeformis at the terrace site was $20.2 \%$ higher than that at the slope site under the same climatic conditions (Fig. 3). During the growing seasons, mean daily canopy transpiration was up to $9.1 \%(p<0.05)$ higher at the terrace site than that at the slope site (Fig. 4). Similarly, Pataki et al. (2000) found an observed decrease in maximum sap flow for Pinus contorta, Abies lasiocarpa, Populus tremuloides, and Pinus flexilis when soil moisture declined by $31.4 \%$. Under the conditions of a saturated shallow

211 water table, forest transpiration could equal PET (Čermák and Prax, 2001). Brito et al. (2015)

212 found that the total canopy transpiration of Pinus canariensis increased by $133 \%$ in a wet year

213 than that in a normal year. Canopy transpiration variation showed significant correlation with

214 soil water content variation (Fig. 5). In addition to soil moisture, the low regression coefficient

215 can be attributed to the influence of various environmental factors (Bosch et al., 2014; Brito et al., 2015; Chen et al., 2014c). Among these factors, VPD and solar radiation can trigger a timely response in transpiration, while the influence of soil water is reflected over a longer temporal

218 scale (Chen et al., 2014a; Shen et al., 2015).

219 As Chen et al. (2014c) indicated that the sensitivity of stomatal response to drought stress can be

220 expressed by the frequency distribution of maxmimum sap flux density. The increased frequency

221 of maximum sap flux density earlier in the day (before 14:00 LT) suggested an enhanced

222 stomatal sensitivity to avoid high VPD (Fig. 7). Studies have shown that the effectiveness of stomatal conductance induced by VPD fluctuation could result in the variation of transpiration rate (Addington et al., 2004; Igarashi et al., 2015), and a decline in canopy conductance with

225 increasing VPD is an indicator of physiological restrictions to transpiration (Chang et al., 2014a;

226 Shen et al., 2015). This occurred to avoid any negative leaf water potential and xylem cavitation

227 (Addington et al., 2004; Wang et al., 2014b). When soil conditions are severely stressed or in a 
Hydrol. Earth Syst. Sci. Discuss., doi:10.5194/hess-2016-223, 2016

Manuscript under review for journal Hydrol. Earth Syst. Sci.

Published: 18 May 2016

(c) Author(s) 2016. CC-BY 3.0 License.
Hydrology and

Earth System

Sciences

Discussions

228 prolonged period of VPD tension, it is inevitable that the varying degrees of embolisms can be

229 caused by runaway cavitation (Vergeynst et al., 2015), which could trigger a series consequences,

230 such as reducing water transport, and stomatal closure (Pataki et al., 2000). This would explain

231 why canopy conductance decreased logarithmically with VPD and reduced sharply when soil

232 water condition changed from wet to dry (Fig. 6). In time and space, soil moisture plays an

233 important role in connecting environmental fluctuations and vegetation transpiration (Brito et al.,

234 2015; Chen et al., 2014a). Similar to the conclusions drawn by Shen et al. (2015), our results

235 showed that canopy transpiration and canopy conductance of P. tabulaeformis were $6.9 \%$ and

$2363.9 \%$ higher at terrace site than that at slope site. Our results suggested that the impact of

237 terracing on transpiration could be explained by the response of canopy transpiration to other

238 environmental factors under different soil water conditions.

2394.3 Implications of this study

240 Under water stress, species tend to adjust their water consumption to avoid reaching water

241 potential values that could produce irreversible damage (Chirino et al., 2011). Depending on

242 their drought avoidance mechanisms, species can be classified into water-spender or water-saver

243 types (Chirino et al., 2011). In this context, $P$. tabulaeformis showed lower sap flux density

244 under drier water conditions (Fig. 3) and reduced canopy conductance with an increasing VPD

245 (Fig. $6 \mathrm{~b}$ and d). Therefore, P. tabulaeformis can be classified as a water-saver species

246 (Heilmeier et al., 2002). Yang et al. (2008) indicated that in the semiarid Loess Plateau, $P$.

247 tabulaeformis uses water more efficiently than Robinia pseudoacacia, and Malus pumila. Similar

248 results were found in mixed forests of different ages (Chang et al., 2013) and different species

249 (Chen et al., 2014b; Nie et al., 2005). In dry regions, P. tabulaeformis might be a good

250 drought-resistance species that could help control soil loss and improve the ecological 
Hydrol. Earth Syst. Sci. Discuss., doi:10.5194/hess-2016-223, 2016

Manuscript under review for journal Hydrol. Earth Syst. Sci.

Published: 18 May 2016

(c) Author(s) 2016. CC-BY 3.0 License.
Hydrology and

Earth System

Sciences

Discussions

(c) $\underset{\mathrm{BY}}{(i)}$

251 environment. In this study, it was found that terracing significantly improved soil water

252 conditions. It captured $113.1 \%$ more REW than that at the slope site (Fig. 2), and it increased

253 canopy transpiration significantly (Fig. 4). Meanwhile, the average DBH, sapwood area, and

254 crown projected area were $12.0 \%, 18.8 \%$, and $63.5 \%$ higher, respectively, at the terrace site than

255 that at the slope site, and the crown projected area showed statistical significance $(p<0.05)$

256 (Table 1). Just as Wang et al. (2012a) have indicated, in drylands, the most efficient use of water

257 is to maximize the productive water loss $(T)$ and minimize the unproductive water loss $(E)$.

258 Terracing increases the accumulation of the limited water supply, making more water available

259 for transpiration and growth and thus, improving the efficiency of water use.

2605 Conclusions

261 In this study, the soil water content variation and daily canopy transpiration of Pinus

262 tabulaeformis were studied over two consecutive growing seasons (2014-2015) in a typical

263 semiarid area of the Loess Plateau in China. The effects of terracing on soil water content,

264 canopy transpiration, and canopy conductance were investigated. Terracing was found to have a

265 statistically significant positive effect on soil water content. $P$. tabulaeformis in the terrace site

266 showed significantly higher canopy transpiration than that in the slope site $(p<0.05)$, and the

267 variation between the terrace and slope sites increased with soil water content variation $(p<$

$2680.0001, R^{2}=0.20$ ). The impact of terracing on transpiration could be expressed through the

269 response of canopy transpiration to other environmental factors. Terracing increased the

270 accumulation of the limited water supply, providing a greater amount of water for transpiration

271 and growth. For sustainable vegetation restoration in semiarid regions, the adoption of terracing

272 could be a technique worthy of consideration. 
Hydrol. Earth Syst. Sci. Discuss., doi:10.5194/hess-2016-223, 2016

Manuscript under review for journal Hydrol. Earth Syst. Sci.

Published: 18 May 2016

(c) Author(s) 2016. CC-BY 3.0 License.

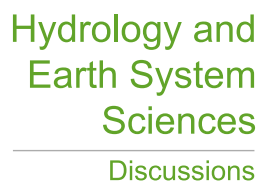

(c) (1)

\section{Acknowledgements}

274 This research was supported by the National Natural Science Foundation of China (41371123,

275 41390462) and the Innovation Project of the State Key Laboratory of Urban and Regional

276 Ecology of China (SKLURE2013-1-02).

277 
Hydrol. Earth Syst. Sci. Discuss., doi:10.5194/hess-2016-223, 2016

Manuscript under review for journal Hydrol. Earth Syst. Sci.

Published: 18 May 2016

(c) Author(s) 2016. CC-BY 3.0 License.
Hydrology and

Earth System

Sciences

Discussions

\section{References}

Addington, R. N., Mitchell, R. J., Oren, R., and Donovan, L. A.: Stomatal sensitivity to vapor pressure deficit and its relationship to hydraulic conductance in Pinus palustris, Tree Physiology, 24, 561-569, 2004.

Bai, X., Gao, J. e., Jia, L., Zhang, M., Ma, R., and Zhang, Y.: Preliminary Study of Effects of Different Terraces on Erosion Control in Loess Plateau, Research of Soil and Water Conservation, 22, 10-15, 2015.

Bosch, D. D., Marshall, L. K., and Teskey, R.: Forest transpiration from sap flux density measurements in a Southeastern Coastal Plain riparian buffer system, Agricultural and Forest Meteorology, 187, 72-82, http://dx.doi.org/10.1016/j.agrformet.2013.12.002, 2014.

Bréda, N., Huc, R., Granier, A., and Dreyer, E.: Temperate forest trees and stands under severe drought: a review of ecophysiological responses, adaptation processes and long-term consequences, Annals of Forest Science, 63, 625-644, 2006.

Brito, P., Lorenzo, J. R., González-Rodríguez, Á. M., Morales, D., Wieser, G., and Jiménez , M. S.: Canopy transpiration of a semi arid Pinus canariensis forest at a treeline ecotone in two hydrologically contrasting years, Agricultural and Forest Meteorology, 201, 120-127, http://dx.doi.org/10.1016/j.agrformet.2014.11.008, 2015.

Čermák, J., and Prax, A.: Water balance of a Southern Moravian floodplain forest under natural and modified soil water regimes and its ecological consequences, Ann. For. Sci., 58, 15-29, 2001.

Chang, J., Wang, Q., Wu, X., Cui, L., and Liu, S.: Water balance of different age Pinus tabulaeformis forests in Taihang Mountain, Shanxi, Scientia Silvae Sinicae, 49, 1-9, 2013. 
Hydrol. Earth Syst. Sci. Discuss., doi:10.5194/hess-2016-223, 2016

Manuscript under review for journal Hydrol. Earth Syst. Sci.

Published: 18 May 2016

(c) Author(s) 2016. CC-BY 3.0 License.
Hydrology and

Earth System

Sciences

Discussions

Chang, X., Zhao, W., Liu, H., Wei, X., Liu, B., and He, Z.: Qinghai spruce (Picea crassifolia) forest transpiration and canopy conductance in the upper Heihe River Basin of arid northwestern China, Agricultural and Forest Meteorology, 198-199, 209-220, http://dx.doi.org/10.1016/j.agrformet.2014.08.015, 2014a.

Chang, X. X., Zhao, W. Z., Liu, H., Wei, X., Liu, B., and He, Z. B.: Qinghai spruce (Picea crassifolia) forest transpiration and canopy conductance in the upper Heihe River Basin of arid northwestern China, Agricultural and Forest Meteorology, 198, 209-220, DOI 10.1016/j.agrformet.2014.08.015, 2014b.

Chen, D., Wang, Y., Liu, S., Wei, X., and Wang, X.: Response of relative sap flow to meteorological factors under different soil moisture conditions in rainfed jujube (Ziziphus jujuba Mill.) plantations in semiarid Northwest China, Agricultural Water Management, 136, 23-33, http://dx.doi.org/10.1016/j.agwat.2014.01.001, 2014a.

Chen, H. S., Shao, M. G., and Li, Y. Y.: Soil desiccation in the Loess Plateau of China, Geoderma, 143, 91-100, DOI 10.1016/j.geoderma.2007.10.013, 2008.

Chen, L., Wang, J., Wei, W., Fu, B., and Wu, D.: Effects of landscape restoration on soil water storage and water use in the Loess Plateau Region, China, Forest Ecology and Management, 259, 1291-1298, http://dx.doi.org/10.1016/j.foreco.2009.10.025, 2010.

Chen, L., Zhang, Z., Zeppel, M., Liu, C., Guo, J., Zhu, J., Zhang, X., Zhang, J., and Zha, T.: Response of transpiration to rain pulses for two tree species in a semiarid plantation, Int $\mathbf{J}$ Biometeorol, 58, 1569-1581, 10.1007/s00484-013-0761-9, 2014b.

Chen, L. X., Zhang, Z. Q., Zha, T. G., Mo, K. L., Zhang, Y., and Fang, X. R.: Soil water affects transpiration response to rainfall and vapor pressure deficit in poplar plantation, New Forest, 45, 235-250, DOI 10.1007/s11056-014-9405-0, 2014c. 
Hydrol. Earth Syst. Sci. Discuss., doi:10.5194/hess-2016-223, 2016

Manuscript under review for journal Hydrol. Earth Syst. Sci.

Published: 18 May 2016

(c) Author(s) 2016. CC-BY 3.0 License.
Hydrology and

Earth System

Sciences

Discussions

Chirino, E., Bellot, J., and Sanchez, J. R.: Daily sap flow rate as an indicator of drought avoidance mechanisms in five Mediterranean perennial species in semi-arid southeastern Spain, Trees-Structure and Function, 25, 593-606, 10.1007/s00468-010-0536-4, 2011.

Courtwright, J., and Findlay, S. G.: Effects of Microtopography on Hydrology, Physicochemistry, and Vegetation in a Tidal Swamp of the Hudson River, Wetlands, 31, 239-249, 10.1007/s13157-011-0156-9, 2011.

Cui, J.: The studies on the relationship of trees water physiology characteristics and soil water in Semi-arid Region on Loess Plateaus, Beijing Forestry University, 2012.

Du, S., Wang, Y.-L., Kume, T., Zhang, J.-G., Otsuki, K., Yamanaka, N., and Liu, G.-B.: Sapflow characteristics and climatic responses in three forest species in the semiarid Loess Plateau region of China, Agricultural and Forest Meteorology, 151, 1-10, 2011.

Engdawork, A., and Bork, H. R.: Long-Term Indigenous Soil Conservation Technology in the Chencha Area, Southern Ethiopia: Origin, Characteristics, and Sustainability, Ambio, 43, 932-942, DOI 10.1007/s13280-014-0527-6, 2014.

FAO: FAO-UNESCO Soil map of the world: Revised legend, world soil resources report 60 , Food and Agriculture Organization of the United Nations, Rome, 1990.

Granier, A.: Une nouvelle méthode pour la mesure du flux de sève brute dans le tronc des arbres, Ann. For. Sci., 42, 193-200, 1985.

Heilmeier, H., Wartinger, A., Erhard, M., Zimmermann, R., Horn, R., and Schulze, E. D.: Soil drought increases leaf and whole-plant water use of Prunus dulcis grown in the Negev Desert, Oecologia, 130, 329-336, 10.1007/s004420100808, 2002.

Huo, Y., and Zhu, B.: Analysis on the Benefits of Level Terrace on Soil and Water Conservation in Loess Hilly Areas, Research of Soil and Water Conservation, 20, 24-28, 2013. 
Hydrol. Earth Syst. Sci. Discuss., doi:10.5194/hess-2016-223, 2016

Manuscript under review for journal Hydrol. Earth Syst. Sci.

Published: 18 May 2016

(c) Author(s) 2016. CC-BY 3.0 License.
Hydrology and

Earth System

Sciences

Discussions

Igarashi, Y., Kumagai, T. o., Yoshifuji, N., Sato, T., Tanaka, N., Tanaka, K., Suzuki, M., and Tantasirin, C.: Environmental control of canopy stomatal conductance in a tropical deciduous forest in northern Thailand, Agricultural and Forest Meteorology, 202, 1-10, http://dx.doi.org/10.1016/j.agrformet.2014.11.013, 2015.

Jian, S., Zhao, C., Fang, S., and Yu, K.: Effects of different vegetation restoration on soil water storage and water balance in the Chinese Loess Plateau, Agricultural and Forest Meteorology, 206, 85-96, http://dx.doi.org/10.1016/j.agrformet.2015.03.009, 2015.

Jin, Z., Dong, Y., Wang, Y., Wei, X., Wang, Y., Cui, B., and Zhou, W.: Natural vegetation restoration is more beneficial to soil surface organic and inorganic carbon sequestration than tree plantation on the Loess Plateau of China, Sci Total Environ, 485, 615-623, 10.1016/j.scitotenv.2014.03.105, 2014.

Kim, D., Oren, R., Oishi, A. C., Hsieh, C.-I., Phillips, N., Novick, K. A., and Stoy, P. C.: Sensitivity of stand transpiration to wind velocity in a mixed broadleaved deciduous forest, Agricultural and Forest Meteorology, 187, 62-71, http://dx.doi.org/10.1016/j.agrformet.2013.11.013, 2014.

LaFevor, M. C.: Restoration of degraded agricultural terraces: Rebuilding landscape structure and process, J Environ Manage, 138, 32-42, DOI 10.1016/j.jenvman.2013.11.019, 2014. Li, H., Wei, W., Chen, L., Guo, E., and Huang, Y.: Progress in the study of soil water balance under forest and grassland covers on the Loess Plateau, Research of Soil \& Water Conservation, 20, 287-293, 2013.

Li, J., Zhang, W. J., and Zhang, J. P.: Comparative Analysis of water reduction benefits between terrace and slope land in southern area of Ningxia: Taking Haoshuichuan Watershed as an 
Hydrol. Earth Syst. Sci. Discuss., doi:10.5194/hess-2016-223, 2016

Manuscript under review for journal Hydrol. Earth Syst. Sci.

Published: 18 May 2016

(c) Author(s) 2016. CC-BY 3.0 License.
Hydrology and

Earth System

Sciences

Discussions

example, Advances in Hydrology and Hydraulic Engineering, Pts 1 and 2, 212-213, 83-87, DOI 10.4028/www.scientific.net/AMM.212-213.83, 2012a.

Li, M., Wang, K., Chen, Z., and Kang, L.: Storage of Water and Sediment Reduction Benefits of

Reverse-slope Terrace under the Different Slopes, Research of Soil and Water Conservation, 18, 100-104, 2011.

Li, X. H., Yang, J., Zhao, C. Y., and Wang, B.: Runoff and Sediment from Orchard Terraces in Southeastern China, Land Degrad Dev, 25, 184-192, Doi 10.1002/Ldr.1160, 2014a.

Li, Y., Zhang, P., Cheng, D., and Xu, W.: A Review Study on the Effect of Slope Fields into Terrace on the Runoff Process in the Water Source Area, Journal of Irrigation and Drainage, 31, $111-114,2012 b$.

Li, Y. Z., Qin, H. Y., Xie, Y. H., Wang, W., Chen, X. S., and Zhang, C. M.: Physiological mechanism for the reduction in soil water in poplar (Populus deltoides) plantations in Dongting Lake wetlands, Wetl Ecol Manag, 22, 25-33, DOI 10.1007/s11273-013-9319-1, 2014b.

Limousin, J. M., Rambal, S., Ourcival, J. M., Rocheteau, A., Joffre, R., and Rodriguez-Cortina, R.: Long-term transpiration change with rainfall decline in a Mediterranean Quercus ilex forest, Global Change Biol, 15, 2163-2175, DOI 10.1111/j.1365-2486.2009.01852.x, 2009.

Luis, V. C., Jiménez, M. S., Morales, D., Kucera, J., and Wieser, G.: Canopy transpiration of a Canary Islands pine forest, Agricultural and Forest Meteorology, 135, 117-123, http://dx.doi.org/10.1016/j.agrformet.2005.11.009, 2005.

Molina, A. J., Latron, J., Rubio, C. M., Gallart, F., and Llorens, P.: Spatio-temporal variability of soil water content on the local scale in a Mediterranean mountain area (Vallcebre, North Eastern Spain). How different spatio-temporal scales reflect mean soil water content, J Hydrol, 516, 182-192, DOI 10.1016/j.jhydrol.2014.01.040, 2014. 
Hydrol. Earth Syst. Sci. Discuss., doi:10.5194/hess-2016-223, 2016

Manuscript under review for journal Hydrol. Earth Syst. Sci.

Published: 18 May 2016

(c) Author(s) 2016. CC-BY 3.0 License.
Hydrology and

Earth System

Sciences

Discussions

(c) $\underset{\mathrm{BY}}{(-)}$

Newman, B. D., Breshears, D. D., and Gard, M. O.: Evapotranspiration Partitioning in a

Semiarid Woodland: Ecohydrologic Heterogeneity and Connectivity of Vegetation Patches,

Vadose Zone Journal, 9, 561-572, 10.2136/vzj2009.0035, 2010.

Nie, L., Li, J., and Zhai, H.: Study of the rate of stem sap flow in Pinus tabulaeformis and

Quercus variabilis by using the TDP method, Acta Ecologica Sinica, 25, 1934-1940, 2005.

Pataki, D. E., Oren, R., and Smith, W. K.: Sap flux of co-occurring species in a western

subalpine forest during seasonal soil drought, Ecology, 81, 2557-2566,

10.1890/0012-9658(2000)081[2557:SFOCOS]2.0.CO;2, 2000.

Shen, Q., Gao, G., Fu, B., and Lü, Y.: Responses of shelterbelt stand transpiration to drought and groundwater variations in an arid inland river basin of Northwest China, J Hydrol, 531, 738-748, http://dx.doi.org/10.1016/j.jhydrol.2015.10.053, 2015.

Stavi, I., Fizik, E., and Argaman, E.: Contour bench terrace (shich/shikim) forestry systems in the semi-arid Israeli Negev: Effects on soil quality, geodiversity, and herbaceous vegetation, Geomorphology, 231, 376-382, 10.1016/j.geomorph.2014.12.028, 2015.

Vergeynst, L. L., Dierick, M., Bogaerts, J. A. N., Cnudde, V., and Steppe, K.: Cavitation: a blessing in disguise? New method to establish vulnerability curves and assess hydraulic capacitance of woody tissues, Tree Physiology, 35, 400-409, 10.1093/treephys/tpu056, 2015. Wang, B., Wen, F., Wu, J., Wang, X., and Hu, Y.: Vertical Profiles of Soil Water Content as Influenced by Environmental Factors in a Small Catchment on the Hilly-Gully Loess Plateau, Plos One, 9, e109546-e109546, 10.1371/journal.pone.0109546, 2014a.

Wang, H. L., Guan, H. D., Deng, Z. J., and Simmons, C. T.: Optimization of canopy conductance models from concurrent measurements of sap flow and stem water potential on 
Hydrol. Earth Syst. Sci. Discuss., doi:10.5194/hess-2016-223, 2016

Manuscript under review for journal Hydrol. Earth Syst. Sci.

Published: 18 May 2016

(c) Author(s) 2016. CC-BY 3.0 License.
Hydrology and

Earth System

Sciences

Discussions

Drooping Sheoak in South Australia, Water Resources Research, 50, 6154-6167, Doi 10.1002/2013wr014818, 2014b.

Wang, L., D'Odorico, P., Evans, J. P., Eldridge, D. J., Mccabe, M. F., Caylor, K. K., and King, E. G.: Dryland ecohydrology and climate change: Critical issues and technical advances, Hydrology \& Earth System Sciences, 16, 2585-2603, 2012a.

Wang, X. C., Li, J., Tahir, M. N., and Fang, X. Y.: Validation of the EPIC model and its utilization to research the sustainable recovery of soil desiccation after alfalfa (Medicago sativa L.) by grain crop rotation system in the semi-humid region of the Loess Plateau, Agr Ecosyst Environ, 161, 152-160, DOI 10.1016/j.agee.2012.07.013, 2012b.

Wang, Y., Shao, M. a., and Shao, H.: A preliminary investigation of the dynamic characteristics of dried soil layers on the Loess Plateau of China, J Hydrol, 381, 9-17, http://dx.doi.org/10.1016/j.jhydrol.2009.09.042, 2010.

Wei, W., Chen, L., Zhang, H., and Chen, J.: Effect of rainfall variation and landscape change on runoff and sediment yield from a loess hilly catchment in China, Environmental Earth Sciences, 73, 1005-1016, 10.1007/s12665-014-3451-y, 2015.

Yang, D., Shao, W., Yeh, P. J. F., Yang, H., Kanae, S., and Oki, T.: Impact of vegetation coverage on regional water balance in the nonhumid regions of China, Water Resources Research, 45, 450-455, 10.1029/2008wr006948, 2009.

Yang, F., Chen, L., Zhu, Q., and Bi, H.: Analysis of water consumption of main afforestation species in western Shanxi of Loess Plateau, Research of Soil and Water Conservation, 15, 41-45, 2008. 
Hydrol. Earth Syst. Sci. Discuss., doi:10.5194/hess-2016-223, 2016

Manuscript under review for journal Hydrol. Earth Syst. Sci.

Published: 18 May 2016

(c) Author(s) 2016. CC-BY 3.0 License.
Hydrology and

Earth System

Sciences

Discussions

(c) (i)

Yang, L., Wei, W., Chen, L., Jia, F., and Mo, B.: Spatial variations of shallow and deep soil moisture in the semi-arid Loess Plateau, China, Hydrol Earth Syst Sc, 16, 3199-3217, DOI 10.5194/hess-16-3199-2012, 2012.

Yuan, Z.-Q., Yu, K.-L., Epstein, H., Fang, C., Li, J.-T., Liu, Q.-Q., Liu, X.-W., Gao, W.-J., and

Li, F.-M.: Effects of legume species introduction on vegetation and soil nutrient development on abandoned croplands in a semi-arid environment on the Loess Plateau, China, Sci Total Environ, 541, 692-700, 10.1016/j.scitotenv.2015.09.108, 2016.

Zhang, H., Wei, W., Chen, L., Yu, Y., Yang, L., and Jia, F.: Analysis of Sap Flow

Characteristics of the Chinese Pine in Typical Loess Plateau Region of China, Environmental Science, 36, 349-356, 2015.

Zhang, J. H., Wang, Y., and Zhang, Z. H.: Effect of terrace forms on water and tillage erosion on a hilly landscape in the Yangtze River Basin, China, Geomorphology, 216, 114-124, DOI 10.1016/j.geomorph.2014.03.030, 2014.

Zhang, X., Zhang, L., Zhao, J., Rustomji, P., and Hairsine, P.: Responses of streamflow to changes in climate and land use/cover in the Loess Plateau, China, Water Resources Research, 44, 2183-2188, 10.1029/2007wr006711, 2008.

Zhang, Y., Cao, N., Wu, M., and Wu, F.: Analysis on soil moisture character of level terrace on the south Loess Plateau, Chinese Agricultural Science Bulletin, 21, 215-220, 2005. 
Hydrol. Earth Syst. Sci. Discuss., doi:10.5194/hess-2016-223, 2016

Manuscript under review for journal Hydrol. Earth Syst. Sci.

Published: 18 May 2016

(c) Author(s) 2016. CC-BY 3.0 License.

\section{Tables}

Table 1. Description of the study sites in Anjiapo catchment.

\begin{tabular}{llll}
\hline & Parameter & \multicolumn{2}{c}{ Type } \\
& & Slope & Terrace \\
\hline Geographical & Plot area $\left(\mathrm{m}^{2}\right)$ & 100 & 100 \\
parameters & Slope aspect & $\mathrm{N}$ & $\mathrm{N}$ \\
& Slope position & Middle & Middle \\
Biological & Dominant plant & Chinese pine & Chinese pine \\
parameters & Sample/total number & $6 / 14$ & $6 / 21$ \\
& DBH (cm) & $12.90^{\mathrm{a}} \pm 3.66$ & $14.45^{\mathrm{a}} \pm 2.40$ \\
& Sapwood area $\left(A_{s}, \mathrm{~cm}^{2}\right)$ & $99.09^{\mathrm{a}} \pm 44.87$ & $117.74^{\mathrm{a}} \pm 33.16$ \\
& Crown projected area $\left(A_{c}, \mathrm{~m}^{2}\right)$ & $9.55^{\mathrm{a}} \pm 3.56$ & $15.61^{\mathrm{b}} \pm 5.11$ \\
& & & \\
\hline
\end{tabular}

Note: slope aspect and slope position were measured by compass; DBH is the diameter at breast height for trees, each parameter was measured from 2014 to 2015. Means without common letters are significantly different at $p<0.05$ according to $t$-test. 
Hydrol. Earth Syst. Sci. Discuss., doi:10.5194/hess-2016-223, 2016

Manuscript under review for journal Hydrol. Earth Syst. Sci.

Published: 18 May 2016

(c) Author(s) 2016. CC-BY 3.0 License.

Hydrology and

(c) (i)

$1 \quad$ Figure Legends

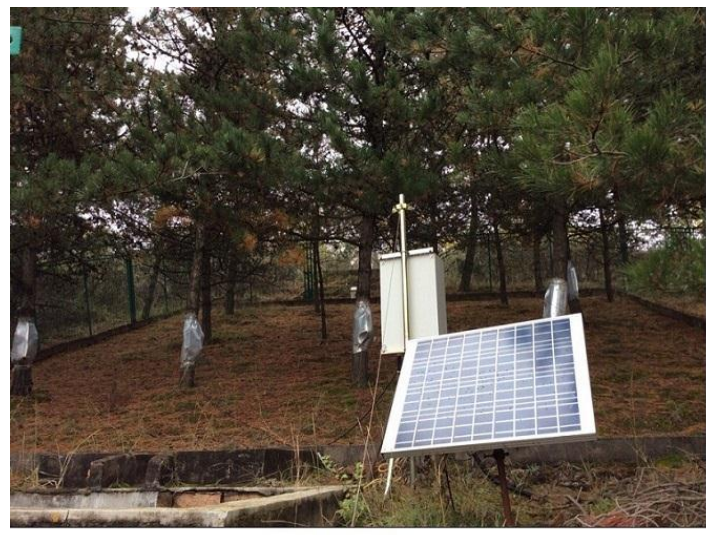

Slope site

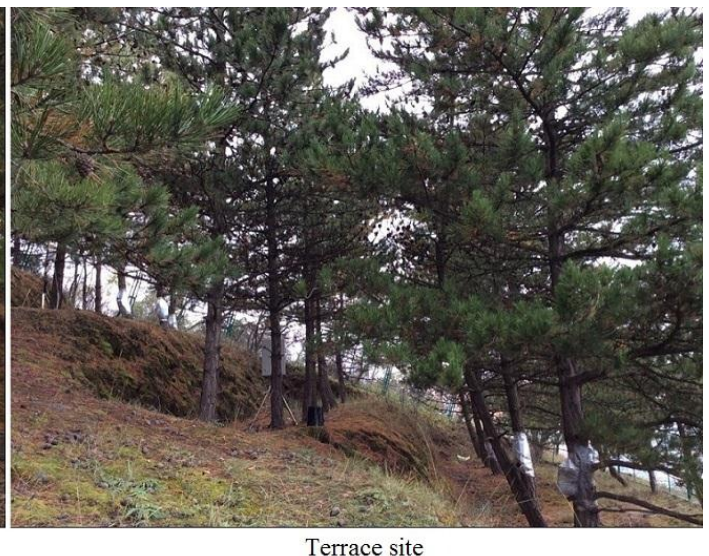

Terrace site

3 Fig. 1 Site photographs of the slope and terrace sites.

4 
Hydrol. Earth Syst. Sci. Discuss., doi:10.5194/hess-2016-223, 2016

Manuscript under review for journal Hydrol. Earth Syst. Sci.
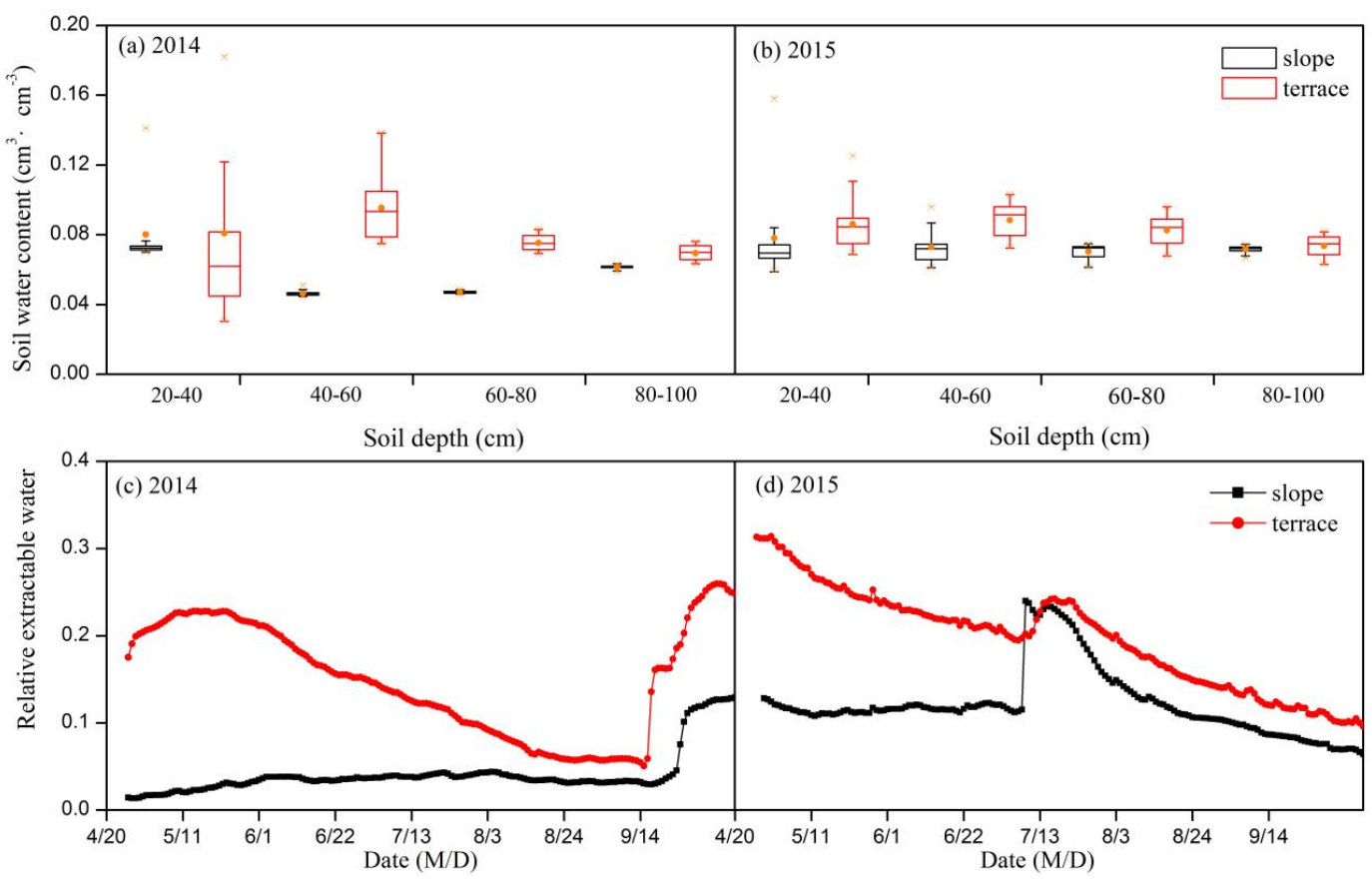

2 Fig. 2 Soil water content of different layers ( $\mathrm{a}$ and $\mathrm{b}$ ) and relative extractable water in the $20-100$

$3 \mathrm{~cm}$ layer (c and d) between the slope and terrace sites during two consecutive growing seasons

4 (2014-2015).

5 
Hydrol. Earth Syst. Sci. Discuss., doi:10.5194/hess-2016-223, 2016

Manuscript under review for journal Hydrol. Earth Syst. Sci.

Published: 18 May 2016

(c) Author(s) 2016. CC-BY 3.0 License.

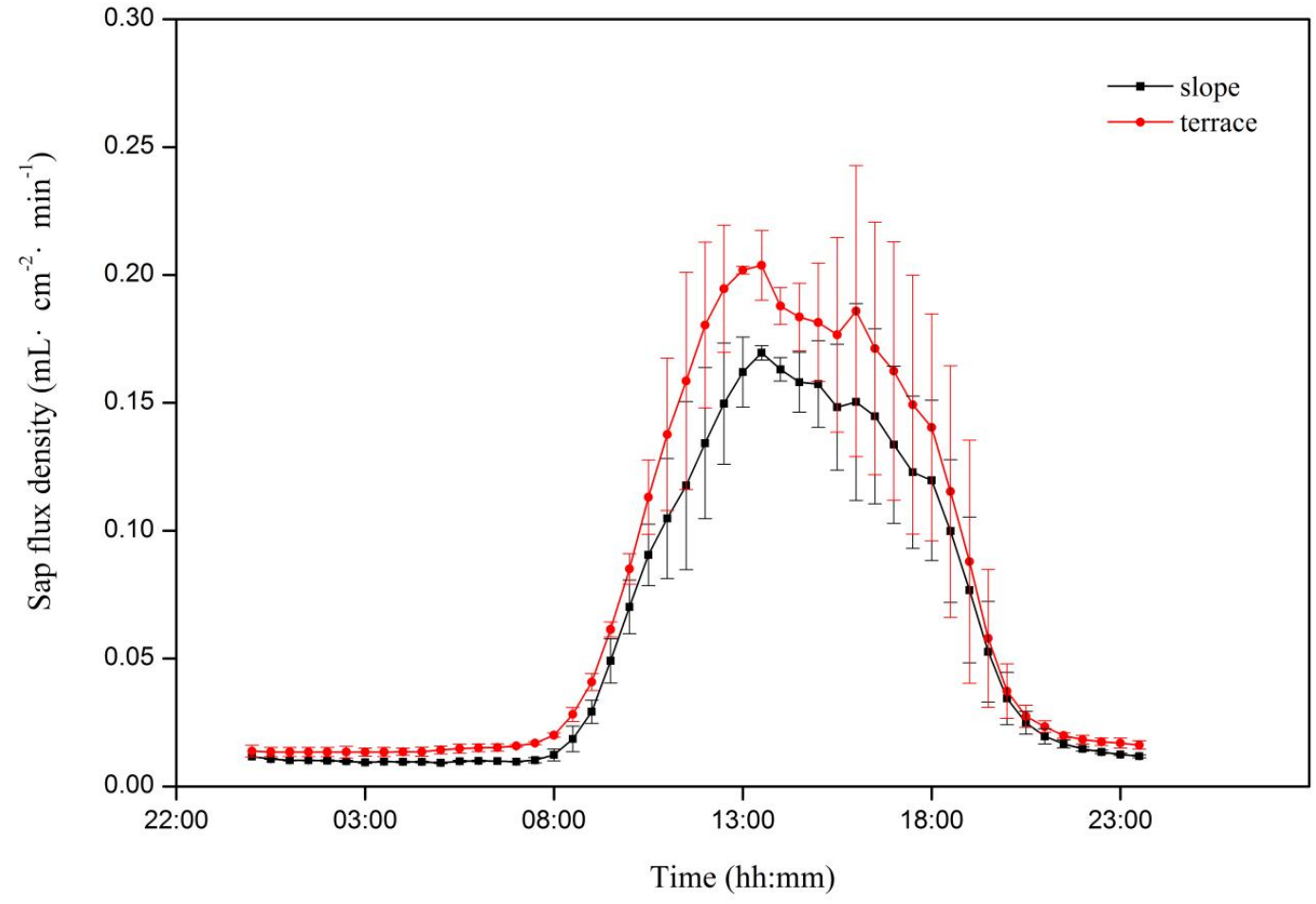

2 Fig. 3 Diurnal time courses of sap flux density at the slope and terrace sites. Data represent

3 means \pm standard deviation $(n=3)$. 
Hydrol. Earth Syst. Sci. Discuss., doi:10.5194/hess-2016-223, 2016

Manuscript under review for journal Hydrol. Earth Syst. Sci.

Published: 18 May 2016

(c) Author(s) 2016. CC-BY 3.0 License.

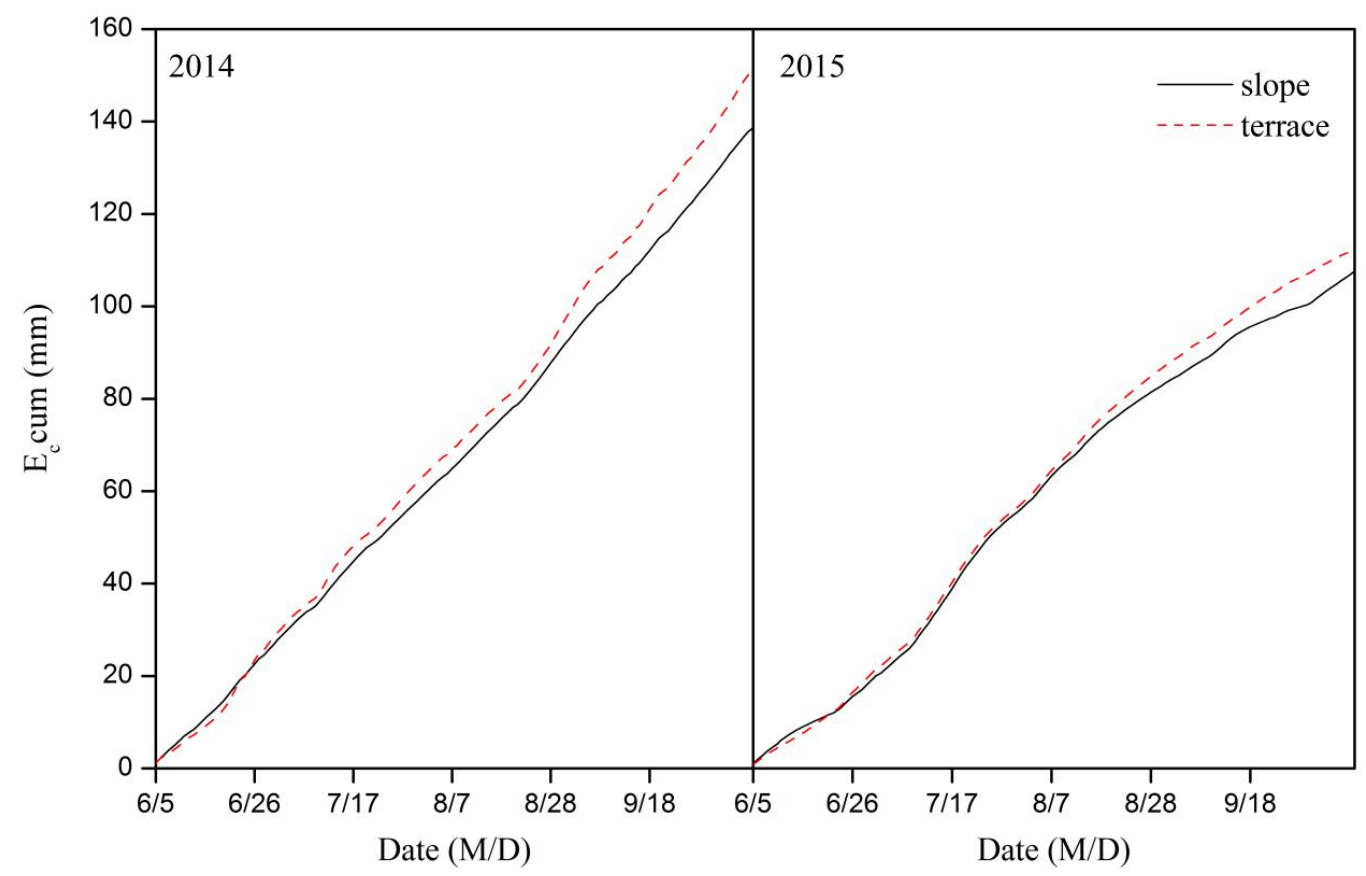

2 Fig. 4 Variation of accumulated canopy transpiration $\left(E_{c}\right.$ cum) during two consecutive growing 3 seasons (2014-2015).

4 
Hydrol. Earth Syst. Sci. Discuss., doi:10.5194/hess-2016-223, 2016

Manuscript under review for journal Hydrol. Earth Syst. Sci.

Published: 18 May 2016

(c) Author(s) 2016. CC-BY 3.0 License.

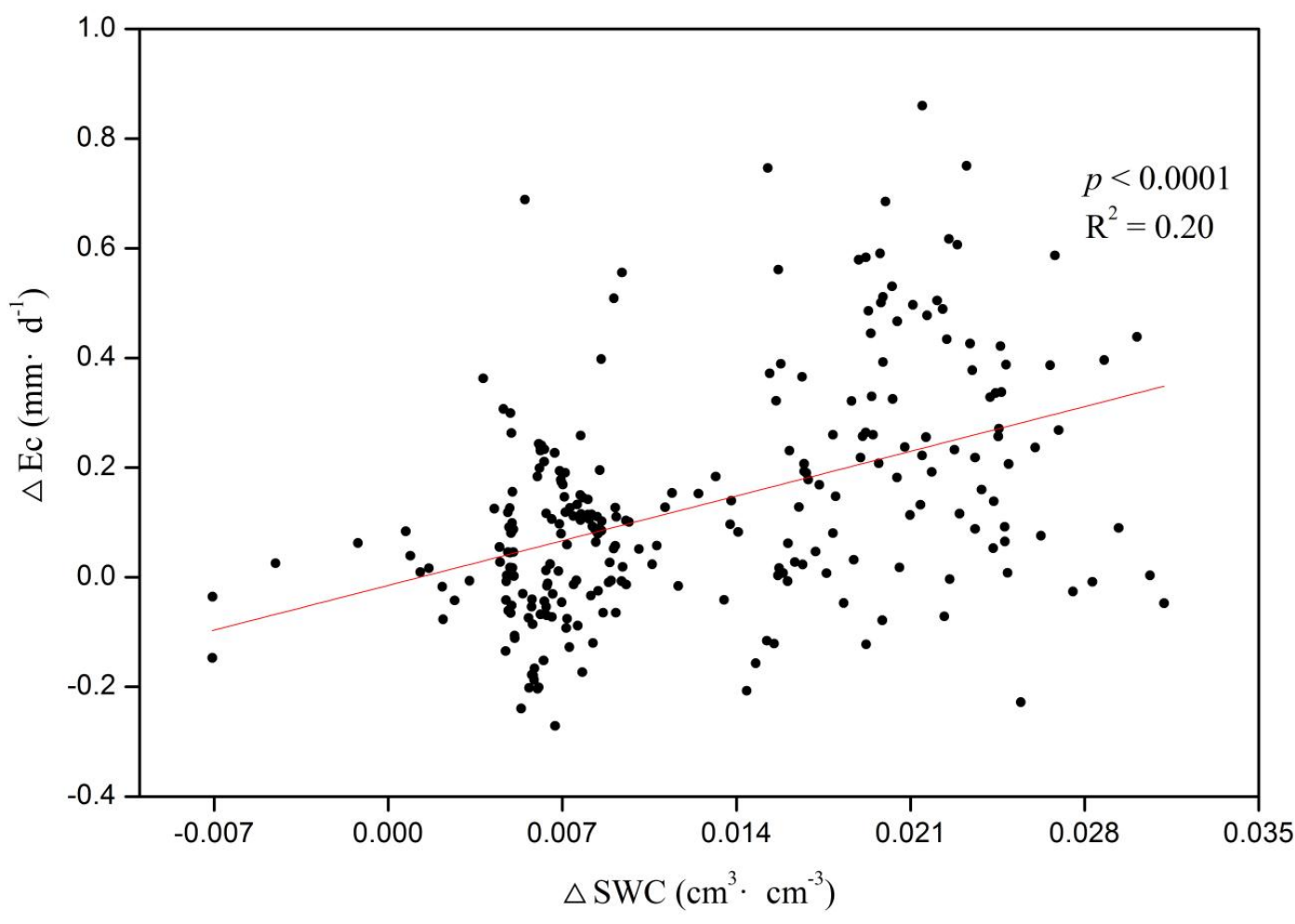

2 Fig. 5 Correlation of $E_{c}$ variation in response to $S W C$ variation within $100 \mathrm{~cm}$ during two

3 consecutive growing seasons (2014-2015). Data of the slope site are the baselines subtracted by

4 those of the terrace site to assess the relationship between $E_{c}$ variation and SWC variation. 
Hydrol. Earth Syst. Sci. Discuss., doi:10.5194/hess-2016-223, 2016

Manuscript under review for journal Hydrol. Earth Syst. Sci.

Published: 18 May 2016

(c) Author(s) 2016. CC-BY 3.0 License.
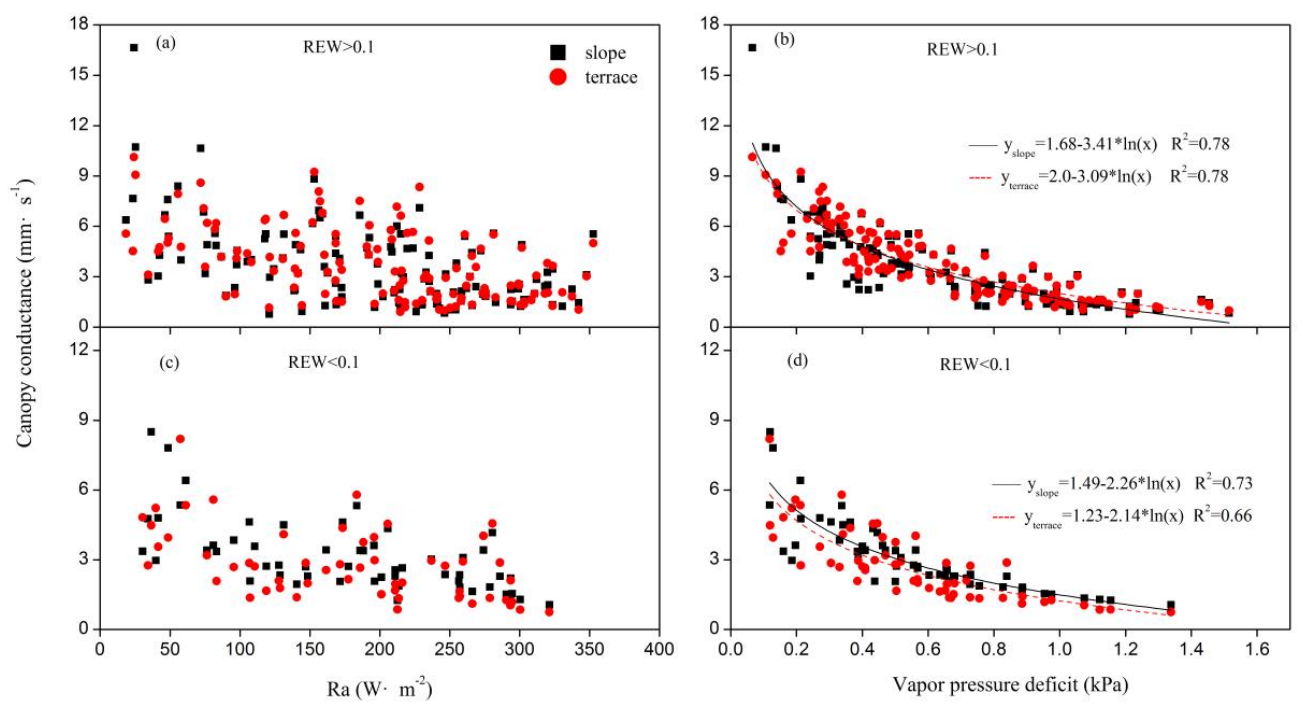

2 Fig. 6 Relationships between canopy conductance and solar radiation (a and c) versus

3 relationships between canopy conductance and vapor pressure deficit ( $\mathrm{b}$ and d) under relatively

4 wet $($ REW > 0.1$)$ and dry $($ REW $<0.1)$ soil conditions.

5 
Hydrol. Earth Syst. Sci. Discuss., doi:10.5194/hess-2016-223, 2016

Manuscript under review for journal Hydrol. Earth Syst. Sci.

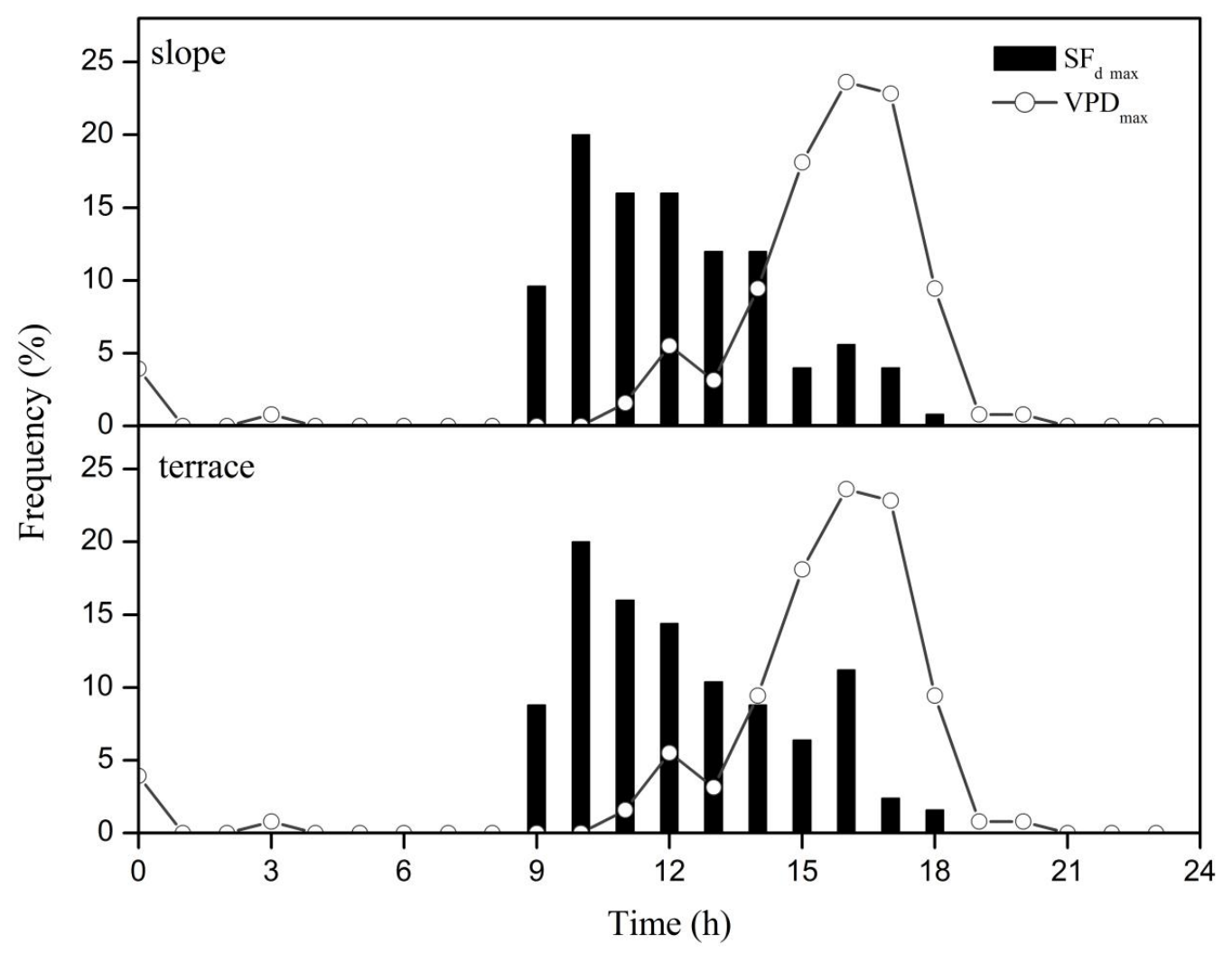

2 Fig. 7 Frequency distribution of maximum sap flux density $\left(\mathrm{SF}_{\mathrm{d}, \max }\right)$ and VPD peak times in the

3 form of diurnal patterns at contrasting sites for the comparison of $\mathrm{SF}_{\mathrm{d}}-\mathrm{VPD}$ evolvement patterns.

4 Data sets cover the growing seasons in 2014 and 2015. 